\title{
Prevalence, Spectrum and Antibiotic Susceptibility of Bacterial and Candida Colonization between the 21st and 33rd Week of Gestation in Women with PPROM - 5 Years' Experience in 1 Perinatal Center
}

Bakterien- und Candida-Besiedlung zwischen der 21. und 33. Schwangerschaftswoche bei Frauen mit vorzeitigem Blasensprung (PPROM): Verbreitung, Spektrum und Resistenz - 5 Jahre Erfahrungen in einem Perinatalzentrum

Authors

Affiliations
J. Reinhard ${ }^{1}$, N. Sänger ${ }^{2}$, L. C. Hanker², S. Peiffer², J. Yuan², V. A. J. Kempf ${ }^{3}$, F. Louwen²

${ }^{1}$ Obstetrics and Gynaecology Department, St. Marienkrankenhaus Frankfurt, Frankfurt am Main

2 Johann Wolfgang Goethe University Frankfurt, Frankfurt am Main

3 Institute for Medical Microbiology and Infection Control, Johann Wolfgang Goethe University Frankfurt, Frankfurt am Main
Key words

- preterm premature rupture of membrane

- antibiotic susceptibility

- bacterial and Candida colonization

- prevalence

Schlüsselwörter

- vorzeitiger Blasensprung

- Antibiotikaresistenz

- Bacteria- und Candida-Kolonisation

- Prävalenz

\section{received $\quad 31.8 .2012$ \\ revised $\quad 15.12 .2012$ \\ accepted 16.12.2012}

\section{Bibliography}

DOI http://dx.doi.org/

10.1055/s-0032-1328132

Geburtsh Frauenheilk 2013; 73 :

59-62 (c) Georg Thieme

Verlag KG Stuttgart · New York · ISSN 0016-5751

\section{Correspondence}

\section{Dr. Joscha Reinhard,}

\section{MBBS BSC (Hon)}

St. Marienkrankenhaus

Frankfurt

Obstetrics and Gynaecology Department

Richard-Wagner Straße 14

60318 Frankfurt am Main

Joscha.Reinhard@kgu.de

\section{Abstract \\ $\nabla$}

Objective: The aim of this study was to evaluate the prevalence, spectrum and antibiotic susceptibility of bacterial and Candida colonization of the vagina between the 21st and the 33rd week of gestation in women who had preterm premature rupture of membranes (PPROM).

Study design: High vaginal swabs from 245 subjects with PPROM were analyzed in a retrospective cohort study using cultivation-dependent methods. Patients were additionally divided into two groups: women with PPROM between the 21st and 27th week of gestation (group A) and women with PPROM between the 28th and 33rd week of gestation (group B). A subgroup analysis comparing the two groups was done.

Results: The prevalence of pathological bacterial colonization was similar in both study groups ( 40.8 vs. $41.4 \%$; $p>0.05$ ), however, a difference in antibiotic susceptibility was noted, which did not reach statistical significance (resistance to ampicillin 71.4 vs. $52.5 \%$; cefuroxime 9.5 vs. $11.7 \%$; gentamicin 28.6 vs. $16.4 \%$; ciprofloxacin 5.0 vs. $5.4 \%)$. In group A there was a statistically significant lower rate of Candida colonization (11.1 vs. 24.3\%; $\mathrm{p}=0.04$ ).

Conclusion: In patients with early PPROM, the rate of Candida colonization (group A) is lower and there are indications of a difference in antibiotic susceptibility of the colonizing bacteria depending on gestational age. Larger study groups are required to confirm these preliminary results.

\section{Introduction}

$\nabla$

In Europe the rate of preterm births is about 5 to $9 \%$ of all births. However in the USA the preterm birth rate is even higher (12-13\%) and the rates are increasing, despite a better knowledge of the

\section{Zusammenfassung \\ $\nabla$}

Einleitung: Ziel dieser Studie ist die Untersuchung von Prävalenz, Spektrum und Antibiotikaresistenz der Bakterien- und Candida-Kolonisation der Scheide nach vorzeitigem Blasensprung in der 21. bis zum Abschluss der 34. Schwangerschaftswoche.

Material und Methode: Hohe vaginale Abstriche von 245 Schwangeren mit vorzeitigem Blasensprung wurden retrospektiv mit Kultivierung analysiert. Eine Subgruppe von Schwangeren in der 21. bis zum Abschluss der 27. Schwangerschaftswoche (Gruppe A) wurde mit Schwangeren in der 28. bis zum Abschluss der 33. Schwangerschaftswoche verglichen.

Ergebnisse: Die Prävalenz bakterieller Kolonisation war in beiden Gruppen in vergleichbarer Häufigkeit vorhanden (40,8 vs. 41,4\%, p>0,05). Es zeigte sich jedoch eine unterschiedliche Antibiotikaresistenz in beiden Gruppen; der Unterschied war statistisch nicht signifikant (Resistenz gegen: Ampicillin 71,4 vs. 52,5\%; Cefuroxim 9,5 vs. $11,7 \%$; Gentamicin 28,6 vs. $16,4 \%$; Ciprofloxacin 5,0 vs. 5,4\%). In Gruppe A zeigte sich eine statistisch signifikant niedrigere Candida-Kolonisation (11,1 vs. $24,3 \%$; $=0,04$ ).

Schlussfolgerung: Schwangere mit sehr frühem vorzeitigem Blasensprung haben eine niedrigere Candida-Kolonisation und möglicherweise eine andere Antibiotikaresistenz abhängig vom Schwangerschaftsalter. Größere Studien sind notwendig, um diese vorläufigen Ergebnisse zu bestätigen.

risk factors involved [1]. This increase is partly due to rising numbers of medically indicated preterm births (for maternal or fetal indications) and to the increase in assisted reproductive technologies $[1,27]$. Children born preterm have a higher risk for major disabilities, such as cerebral palsy 
and respiratory morbidity, and are more likely to develop behavioral and educational difficulties [2,3]. The risk of subsequent morbidities and long-term problems is increased in children born at a younger gestation age $[2,3,26]$. $25 \%$ to $30 \%$ of preterm births are associated with preterm premature rupture of membranes (PPROM). Thus, optimal management of patients with PPROM is a major priority in the prevention of preterm birth. Causes of and risk factors for PPROM are multifactorial and include uterine ischemia or hemorrhage, tobacco exposure, however the most important causes are infection and inflammation [1]. Di Giulio et al. demonstrated that microbial invasion of the amniotic cavity affected half of all patients with PPROM (detected by molecular methods), although invasion was frequently not detected using culture-based methods, which suggests that molecular techniques (e.g. PCR) may be more sensitive for the detection of amniotic infections [4-6]. The same study group found PPROM to be more frequently associated with Candida spp. infection than was previously known [4]. The pathophysiology of infection causing PPROM is considered to be due to the production of prostaglandins and matrix-degrading enzymes via microbial endotoxins and pro-inflammatory cytokines (e.g. IL-8, IL1 $\beta$, TNF $\alpha$ ) which, in turn, are released after the binding of microorganisms to patternrecognition receptors (e.g. toll-like receptors) [1]. Prostaglandins play a major role in stimulating uterine contractions, while degradation of the extracellular matrix in fetal membranes is implicated in PPROM [1,7]. However, infection caused by ascending microorganisms may also occur secondary to PPROM [8,9]. Intrauterine infection has been demonstrated in up to $60 \%$ of cases [8, 9]. More recent data suggest that some microbes invade the amniotic cavity from the bloodstream after dissemination from remote sites, e.g. from the gastrointestinal tract [4].

The appropriate therapy for women with PPROM is still unclear. The ORACLE Children Study found that the administration of antibiotics to patients with PPROM was neither beneficial nor harmful for children's health at a follow-up of 7 years [10-12]. In women who had spontaneous labor with no preterm rupture of membranes, there was some evidence of fetal harm due to the administration of antibiotics. This highlights the importance of ascertaining that the diagnosis of PPROM is correct before prescribing antibiotics $[11,12]$.

In patients with PPROM, the administration of antibiotics appears to offer some benefit, especially at an earlier gestational age ( $<32$ weeks), and is associated with significant benefits in short-term outcomes (prolongation of pregnancy, prevention of chorioamnionitis and neonatal infection). Thus, antibiotic therapy is still the standard of care $[13,14]$. However, if antibiotics are prescribed, it is still unclear which should be the antibiotic of choice. Penicillins and macrolide antibiotics can be administered alone or in combination, parenterally or orally. The administration of amoxicillin plus clavulanic acid to pregnant mothers was found to be associated with a significantly higher risk of necrotizing enterocolitis in infants after delivery, and it was recommended not to prescribe this combination to pregnant women $[15,16]$. Thus, more information on the prevalence, spectrum and antibiotic sensitivity of bacterial and Candida colonization is important to determine the optimal treatment strategies for patients with PPROM. The aim of our study was therefore to provide data on the prevalence and antibiotic sensitivity of bacterial and Candida colonization in patients with PPROM to improve the knowledge base for decisions on the use of specific antibiotics. We also carried out a subgroup analysis comparing prevalence, sensitivity and colonization in early PPROM (21st - 27th week of gestation) with that in late PPROM (28th - 34th week of gestation).

\section{Methods}

$\nabla$

\section{Study population}

All samples were collected at the perinatal center of Johann Wolfgang Goethe University Frankfurt, Germany, between June 2006 and May 2011. A retrospective cohort study was done in patients with PPROM who met the following inclusion criteria: (i) gestational age between 21 and 34 weeks, and (ii) high vaginal swabs taken on admission to hospital for microbiological diagnosis prior to receiving antibiotic treatment. A subgroup analysis was done to compare findings in the 21st to 27th week of gestation (group A) with those in the 28th to 33rd week of gestation (group B).

\section{Study protocol}

Membrane rupture was diagnosed by insulin-like growth factor binding protein-1 (IGFBP-1; Actim ${ }^{\circledR}$ PROM). After the diagnosis of PPROM, a high vaginal swab was taken for microbiological culture of aerobic and anaerobic bacteria and fungi. Microbiological culture techniques were performed in accordance with standard laboratory techniques [17]. Bacterial susceptibility testing was done according to the recommendations of the Clinical and Laboratory Standards Institute, Wayne, PA, USA [18]. All procedures were performed by the routine diagnostic laboratories of the Institute of Medical Microbiology and Infection Control of the University Hospital of Frankfurt (Germany). These laboratories are certified in accordance with DIN EN ISO/IEC 17025 and 15189 standards (laboratory identification code: D-ML-013102-01 and D-PL-13102-01-00).

\section{Statistical analysis}

All results are shown as mean values \pm standard deviation. Wilcoxon signed rank test and Fisher's exact test were used for statistical analysis. Analysis was done using SPSS Statistics 17.0 software (Scientific Packages for the Social Sciences, Inc., Chicago, IL, USA). A value of $\mathrm{p}<0.05$ for a two-tailed test was considered statistically significant.

\section{Results}

$\nabla$

Cervical swabs obtained from 245 subjects with PROM were analyzed. Table 1 presents the baseline characteristics of the 245 enrolled patients. Aerobic bacteria were identified with culture testing ( Table 2 ).

The cervical prevalence of bacteria which colonize normal vaginal flora (Escherichia [E.] coli, Streptococcus agalactiae, Klebsiella spp. etc.) and are potentially involved in amniotic infections was similar in both study groups ( 40.8 vs. $41.4 \%$; $p>0.05$ ), however a difference in the susceptibility to antibiotics was noted, although this difference was not statistically significant (overall resistance to ampicillin 71.4 vs. $52.5 \%$; resistance to cefuroxime 9.5 vs. $11.7 \%$; resistance to gentamicin 28.6 vs. $16.4 \%$; resistance to ciprofloxacin 5.0 vs. 5.4\%). Table 3 shows the individual susceptibility to antibiotics for the majority of pathogenic bacteria. Group A had a significantly lower rate of Candida colonization (11.1 vs. $24.3 \% ; p=0.04$ ) and the difference was statistically significant. 
Table 1 Characteristics of the study population ( $n=245 ; n$. s. $=$ not significant).

\begin{tabular}{|c|c|c|c|}
\hline \multirow[t]{2}{*}{ Characteristic } & Group A & Group B & p-value \\
\hline & 21 st to 27 th week of gestation ( $n=56$ ) & 28th to 33 rd week of gestation $(n=189)$ & \\
\hline Maternal age (years) & $32.6 \pm 4.3$ & $33.0 \pm 5.4$ & n.s. \\
\hline Nulliparity & $62.3 \%(33 / 53)$ & $67.1 \%(110 / 164)$ & n.s. \\
\hline Candida colonization & $11.1 \%(6 / 54)$ & $24.3 \%(37 / 152)$ & 0.04 \\
\hline Bacterial colonization & $40.8 \%(21 / 54)$ & $41.4 \%(63 / 152)$ & n.s. \\
\hline Normal vaginal bacteria & $55.6 \%(30 / 54)$ & $46.1 \%(70 / 152)$ & n.s. \\
\hline \multicolumn{4}{|l|}{ Overall resistance } \\
\hline ampicillin & $71.4 \%(15 / 21)$ & $52.5 \%(32 / 61)$ & n.s. \\
\hline cefuroxime & $9.5 \%(2 / 35)$ & $11.7 \%(7 / 60)$ & n.s. \\
\hline gentamicin & $28.6 \%(6 / 35)$ & $16.4 \%(10 / 61)$ & n.s. \\
\hline ciprofloxacin & $5.0 \%(1 / 20)$ & $5.4 \%(3 / 56)$ & n.s. \\
\hline
\end{tabular}

Table 2 Bacteria identified on culture ( $n=206 ; n$. s. = not significant).

\begin{tabular}{|c|c|c|c|}
\hline Bacteria species & $\begin{array}{l}\text { Group A } \\
21 \text { st to } 27 \text { th week of gestation }(n=54)\end{array}$ & $\begin{array}{l}\text { Group B } \\
\text { 28th to 33rd week of gestation ( } n=152)\end{array}$ & $\begin{array}{l}\mathrm{p} \text { (Fisher's } \\
\text { exact test) }\end{array}$ \\
\hline E. coli & $5.6 \%(3 / 54)$ & $13.2 \%(20 / 152)$ & n.s. \\
\hline Enterococcus faecalis & $0 \%(0 / 54)$ & $0.7 \%(1 / 152)$ & n.s. \\
\hline Staphylococcus aureus & $5.6 \%(3 / 54)$ & $2.6 \%(4 / 152)$ & n.s. \\
\hline Normal vaginal species & $55.6 \%(30 / 54)$ & $46.1 \%(70 / 152)$ & n.s. \\
\hline Streptococcus agalactiae & $5.6 \%(3 / 54)$ & $5.3 \%(8 / 152)$ & n.s. \\
\hline Streptococcus dysgalactiae & $0 \%(0 / 54)$ & $0.7 \%(1 / 152)$ & n.s. \\
\hline Klebsiella pneumoniae & $5.6 \%(3 / 54)$ & $3.3 \%(5 / 152)$ & n.s. \\
\hline Klebsiella oxytoca & $3.7 \%(2 / 54)$ & $0 \%(0 / 152)$ & n.s. \\
\hline Salmonella enteritidis & $0 \%(0 / 54)$ & $0.7 \%(1 / 152)$ & n.s. \\
\hline Enterobacter cloacae & $0 \%(0 / 54)$ & $2.6 \%(4 / 152)$ & n.s. \\
\hline Pseudomonas aeruginosa & $0 \%(0 / 54)$ & $0.7 \%(1 / 152)$ & n.s. \\
\hline Proteus mirabilis & $0 \%(0 / 54)$ & $1.3 \%(2 / 152)$ & n.s. \\
\hline Proteus vulgaris & $0 \%(0 / 54)$ & $0.7 \%(1 / 152)$ & n.s. \\
\hline Citrobacter koseri & $0 \%(0 / 54)$ & $0.7 \%(1 / 152)$ & n.s. \\
\hline Acinetobacter /woffii & $0 \%(0 / 54)$ & $1.3 \%(2 / 152)$ & n.s. \\
\hline No growth & $18,5 \%(10 / 54)$ & $20.4 \%(31 / 152)$ & n.s. \\
\hline
\end{tabular}

Table 3 Resistance of E. coli, Streptococcus agalactiae and Klebsiella spp. ( $\mathrm{n}=245$; n. s. = not significant).

\begin{tabular}{|c|c|c|c|}
\hline Characteristic & $\begin{array}{l}\text { Group A } \\
21 \text { st to } 27 \text { th week of gestation }(n=56)\end{array}$ & $\begin{array}{l}\text { Group B } \\
\text { 28th to } 33 \text { rd week of gestation }(n=189)\end{array}$ & p-value \\
\hline \multicolumn{4}{|l|}{ E. coli resistance } \\
\hline ampicillin & $66.7 \%(8 / 12)$ & $55.0 \%(22 / 40)$ & n.s. \\
\hline cefuroxime & $16.7 \%(2 / 12)$ & $2.5 \%(1 / 40)$ & n.s. \\
\hline - gentamicin & $25.0 \%(3 / 12)$ & $5.0 \%(2 / 40)$ & n.s. \\
\hline - ciprofloxacin & $8.3 \%(1 / 12)$ & $7.5 \%(3 / 40)$ & n.s. \\
\hline \multicolumn{4}{|c|}{ Streptococcus agalactiae resistance } \\
\hline ampicillin & $0 \%(0 / 2)$ & $0 \%(0 / 6)$ & n.s. \\
\hline cefuroxime & $0 \%(0 / 2)$ & $0 \%(0 / 6)$ & n.s. \\
\hline gentamicin & $100 \%(2 / 2)$ & $100 \%(6 / 6)$ & n.s. \\
\hline ciprofloxacin & $0 \%(0 / 2)$ & $0 \%(0 / 6)$ & n.s. \\
\hline \multicolumn{4}{|c|}{ Klebsiella spp. resistance } \\
\hline ampicillin & $100 \%(4 / 4)$ & $100 \%(1 / 1)$ & n.s. \\
\hline cefuroxime & $0 \%(0 / 4)$ & $0 \%(0 / 1)$ & n.s. \\
\hline gentamicin & $0 \%(0 / 4)$ & $0 \%(0 / 1)$ & n.s. \\
\hline - ciprofloxacin & $0 \%(0 / 4)$ & $0 \%(0 / 1)$ & n.s. \\
\hline
\end{tabular}

\section{Conclusion}

$\nabla$

The study showed that the prevalence of bacteria colonizing the normal vaginal flora and potentially involved in amniotic infection in PPROM was around $41 \%$ for both subgroups. These results correspond to previously published data $[4,19,20]$. It is interest- ing to note that 10 and $71 \%$, respectively, of detected bacterial species were resistant to the commonly used broad-spectrum antibiotics cefuroxime and ampicillin. The major pathogenic bacteria showed a varied susceptibility to antibiotics ( Table 3). Different antibiotic susceptibilities were noted for group A (21st to 27 th week of gestation) compared to group B (28th to 33rd week 
of gestation). Group A showed a higher resistance to broad-spectrum ampicillin (71.4 vs. 52.5\%) while resistance to cefuroxime was higher in group B, although at a markedly lower level (9.5 vs. $11.7 \%$ ). These findings are in accordance with data showing increasing numbers of antibiotic-resistant $E$. coli infections among preterm infants. Ampicillin-resistant E. coli infections would seem to be linked to prolonged antenatal administration of antibiotics in cases with PPROM and appear to preferentially affect preterm infants [21]. Furthermore, the intrapartum administration of ampicillin has been shown to be an independent risk factor for ampicillin-resistant $E$. coli early-onset sepsis and also increases E. coli late-onset sepsis [21]. Thus, there is a need for further and larger studies evaluating the bacterial spectrum and antibiotic sensitivity in patients with PPROM, with a special focus on certain subgroups of patients, as the data suggests that different treatment approaches should be used for patients in the 21 st to 27 th week of gestation and for patients in the 28th to 33rd week of gestation. We found some aerobic bacteria, but most vaginal bacteria are anaerobic, especially in women with bacterial vaginosis which commonly affects around $20 \%$ of the study population [22].

Special emphasis should be laid on treating Candida colonization, especially later in pregnancy, as our subgroup B had a significantly higher rate of Candida colonization (11.1 vs. 24.3\%; $\mathrm{p}=0.04$ ). The finding that Candida colonization is significantly higher later on in pregnancy is well known [23]; two studies noted the impact of vaginal Candida colonization on preterm birth but it is still not fully understood and has not been investigated in prospective studies [24,25]. As mentioned above, infection with Candida spp. was found to be more frequently associated with PPROM than was previously thought [4] and that effective therapy should be administered to prevent preterm birth.

Future studies should include outcome measures (e.g. intraamniotic inflammation at presentation, histopathologic inflammation of the placenta and chorioamniotic membranes at delivery) as well as pregnancy and perinatal outcomes.

\section{Clinical Practice \\ $\nabla$}

Around $41 \%$ of women with PPROM have pathological bacterial contamination of the vagina resistant to the most commonly administered broad-spectrum antibiotics ampicillin and cefuroxime.

\section{Conflict of Interest}

$\nabla$

None.

\section{References}

1 Goldenberg RL, Culhane JF, Iams JD et al. Epidemiology and causes of preterm birth. Lancet 2008; 371: 75-84

2 Marlow N, Wolke D, Bracewell MA; EPICure Study Group. Neurologic and developmental disability at six years of age after extremely preterm birth. N Engl J Med 2005; 352: 9-19

3 Melamed N, Klinger G, Tenenbaum-Gavish $\mathrm{K}$ et al. Short-term neonatal outcome in low-risk, spontaneous, singleton, late preterm deliveries. Obstet Gynecol 2009; 114: 253-260

4 DiGiulio DB, Romero R, Kusanovic JP et al. Prevalence and diversity of microbes in the amniotic fluid, the fetal inflammatory response, and pregnancy outcome in women with preterm pre-labor rupture of membranes. Am J Reprod Immunol 2010; 64: 38-57
5 DiGiulio DB, Gervasi MT, Romero R et al. Microbial invasion of the amniotic cavity in pregnancies with small-for-gestational-age foetuses. J Perinat Med 2010; 38: 495-502

6 DiGiulio DB, Gervasi MT, Romero R et al. Microbial invasion of the amniotic cavity in preeclampsia as assessed by cultivation and sequencebased methods. J Perinat Med 2010; 38: 503-513

7 Romero R, Baumann P, Gomez R et al. The relationship between spontaneous rupture of membranes, labor, and microbial invasion of the amniotic cavity and amniotic fluid concentrations of prostaglandins and thromboxane B2 in term pregnancy. Am J Obstet Gynecol 1993; 168: $1654-1664$

8 Mercer BM, Goldenberg RL, Das AF et al. What we have learned regarding antibiotic therapy for the reduction of infant morbidity after preterm premature rupture of the membranes. Semin Perinatol 2003; 27: 217-230

9 Mercer BM. Preterm premature rupture of the membranes. Obstet Gynecol 2003; 1101: 178-193

10 Kenyon S, Pike K, Jones DR et al. Childhood outcomes after prescription of antibiotics to pregnant women with preterm rupture of the membranes: 7-year follow-up of the ORACLE I trial. Lancet 2008; 372: 1310-1318

11 Kenyon S, Pike K, Jones DR et al. Childhood outcomes after prescription of antibiotics to pregnant women with preterm rupture of the membranes: 7-year follow-up of the ORACLE II trial. Lancet 2008; 372: 1319-1327

12 Kenyon S, Brockelhurst P, Jones D et al. MRC ORACLE Children Study. Long term outcomes following prescription of antibiotics to pregnant women with either spontaneous preterm labour or preterm rupture of the membranes. BMC Pregnancy Childbirth 2008; 8: 14

13 Yudin $M H$, van Schalkwyk J, van Eyk $N$ et al. Antibiotic therapy in preterm premature rupture of the membranes. SOGC Clinical Practice Guideline 2009. http://www.sogc.org/guidelines/documents/gui233 CPG0909.pdf; last access: 8.1.2013

14 Kenyon S, Bolvain M, Neilson JP. Antibiotics for preterm rupture of membranes. Cochrane Database Syst Rev 2010; 8: CD001058

15 Kenyon SL, Taylor DJ, Tarnow-Mordi W; ORACLE Collaborative Group. Broad-spectrum antibiotics for spontaneous preterm labour: the ORACLE I randomised trial. Lancet 2001; 357: 979-988

16 Kenyon SL, Taylor DJ, Tarnow-Mordi W; ORACLE Collaborative Group. Broad-spectrum antibiotics for spontaneous preterm labour: the ORACLE II randomised trial. Lancet 2001; 357: 989-994

17 Versalovic J, Carroll KC, Funke G et al. Manual of clinical Microbiology. 10th edition. Washington: American Society of Microbiology; 2011

18 Cockerill FR. Performance standards for antimicrobial susceptibility testing. http://www.clsi.org; last access: 8.1.2013

19 Reinhard J, Heinrich TM, Reichenbach L et al. Prevalence, spectrum and sensitivity of bacterial and fungal infection at 21st to 33rd weeks gestational age with preterm rupture of membrane -5 years of experience in 1 perinatal centre. Z Geburtshilfe Neonatol 2011; 215: PO05_05

20 Wild J, Küssel L, Zeisler H. Der frühe vorzeitige Blasensprung. Geburtsh Frauenheilk 2010; 70: P38

21 Kuhn P, Dheu C, Bolender C et al. Incidence and distribution of pathogens in early-onset neonatal sepsis in the era of antenatal antibiotics. Paediatr Perinat Epidemiol 2010; 24: 479-487

22 Salah RM, Allam AM, Magdy AM et al. Bacterial vaginosis and infertility: cause or association? Eur J Obstet Gynecol Reprod Biol 2012; DOI: 10.1016/j.ejogrb.2012.10.031

23 Mendling W, Schnell JD. Antepartal vaginal yeast contamination today. Mykosen 1984; 27: 573-578

24 Czeizel AE, Fladung B, Vargha P. Preterm birth reduction after clotrimazole treatment during pregnancy. Eur J Obstet Gynecol Reprod Biol 2004; 116: 157-163

25 Kiss H, Petricevic L, Husslein P. Prospective randomised controlled trial of an infection screening programme to reduce the rate of preterm delivery. BMJ 2004; 329: 371

26 Kagan KO, Hoopmann M, Kozlowski P. Assessment of foetal DNA in maternal blood - a useful tool in the hands of prenatal specialists. Geburtsh Frauenheilk 2012; 72: 998-1003

27 Beckmann MW, Bader W, Bechtold I et al. Finanzierung und finanzielle Probleme von Leistungen und Strukturen im Fachgebiet Gynäkologie und Geburtshilfe im Jahr 2011 - allgemeine Aspekte und geburtshilfliche Versorgung. II. Artikel der Finanzierungskommission der DGGG e.V. - Teil I. Geburtsh Frauenheilk 2011; 71: 367-380 